\title{
Cookies Tepung Komposit Mocaf Dan Tempe Koro Gude (Cajanuscajan) Ditinjau Dari Sifat Sensori, Kimia Dan Aktivitas Antioksidan
}

\author{
Christiana Retnaningsih, Talentea Cezar Juniarti, Meiliana \\ Program Studi Teknologi Pangan Fakultas Teknologi Pertanian \\ Unika Soegijapranata Semarang \\ email:nik@unika.ac.id
}

\begin{abstract}
Abstrak
Cookies dari tepung mocaf dan tepung koro gude dimaksukan untuk meningkatkan pemanfaatan bahan pangan local. Tujuan penelitian ini untuk mengetahui tingkat kesukaan panelis terhadap produk cookies mocaf dan tepung tempe koro gude, serta mengetahui karakteristik fisikokimia dari produk tersebut..Metode yang digunakan penelitian ini meliputi pembuatan tepung tempe koro gude, pembuatan cookies mocaf dan tepung tempe koro gude, uji organoleptik, analisa kimia yang meliputi kadar air, kadar abu, kadar protein, kadar lemak, kadar karbohidrat dan aktivitas antioksidan. Hasil penelitian uji organoleptik terhadap lima formulasi cookies F0, F1, F2, F3, dan F4, pada parameter rasa, warna dan overall menunjukkan tidak ada perbedaan nyata antar perlakuan pada tingkat kepercayaan $95 \%(\mathrm{p} \leq 0,05)$. Dua formulasi terbaik cookies mocaf dan tepung tempe koro gude pada semua parameter dihasilkan oleh F2 dan F3 dan dilanjutkan dengan analisa kimia dan aktivitas antioksidan. Hasil uji kadar air nilai tertinggi didapat sampel cookies $\mathrm{F} 3$ sebesar 4,99\%, kadar protein nilai tertinggi didapat sampel cookies F3 sebesar 7,59\% dan aktivitas antioksidan nilai tertinggi didapat sampel cookies F3 sebesar 21,13\%, nilai signifikansi menunjukkan ada beda nyata antar perlakuan pada tingkat kepercayaan 95\% ( $\mathrm{P}<0,05)$, sedangkan kadar abu, kadar lemak dan kadar karbohidrat nilai signifikansi menunjukkan tidak berbeda nyata antar perlakuan.
\end{abstract}

Kata kunci : Cookies, Mocaf,Tepung Tempe Koro Gude

\section{PENDAHULUAN}

Pada umumnya cookies dibuat dari tepung terigu. dengan kadar protein rendah yaitu $8-9,5 \%$, (Rosmisari, 2006). Tepung terigu merupakan salah satu produk impor yang bisa disubstitusi dengan bahan baku lokal seperti tepung mocaf dan tepung tempe koro gude (Asmawan et al., 2014). Tepung mocaf memiliki kandungan pati yang tinggi (87,3\%), dibandingkan tepung terigu sebesar $60-68 \%$ dan tepung mocaf tidak mengandung gluten. Tepung mocaf diketahui memiliki kandungan protein rendah $\pm 1,2 \%$ sedangkan kandungan protein tepung terigu $\pm 8-13 \%$ (Salim, 2011). Untuk meningkatkan kandungan protein dalam produk cookies maka diperlukan substitusi dengan bahan pangan lain seperti koro gude. Kandungan protein yang terdapat dalam tepung koro gude yaitu sebesar 29,42g/100g (Tiwari et al., 2011).

Koro gude merupakan golongan kacang-kacangan yang cukup dikenal oleh masyarakat tetapi pengolahannya menjadi bahan pangan masih terbatas. Hal ini karena koro gude memiliki faktor antinutrisi, sehingga belum banyak orang memanfaatkannya sebagai bahan pangan komersial. Salah satunya koro gude memiliki kandungan asam fitat dan tannin yang bersifat toksik. Tannin membentuk senyawa kompleks dengan protein dan karbohidrat yang dapat mengurangi/menghambat aktivitas amilase dan lipase pada pakreas serta menghambat 
penyerapan Fe. Kandungan antinutrisi tersebut dapat dikurangi melalui beberapa proses seperti penghancuran, perendaman, pengirisan, perebusan, pengeringan, pengupasan dan fermentasi seperti dibuat tempe (Winarno, 2004). Selain zat antinutrisi, koro gude memiliki kandungan antioksidan antara lain polifenol, antosianin dan flavonoid (Loganayaki, 2011).

Tujuan penelitian ini adalah untuk mengetahui tingkat kesukaan panelis terhadap produk cookies tepung komposit mocaf dan tempe koro gude, serta mengetahui karakteristik kimia dan aktivitas antioksidannya.

\section{METODE}

Penelitian dilakukan dengan pentahapan sesuai dengan Gambar 1 . Pembuatan tepung tempe koro gude dilakukan untuk membuat formulasi cookies. Kemudian dilakukan pembuatan cookies dengan 5 formulasi cookies. Selanjutnya analisa sensori untuk mengetahui tingkat penerimaan konsumen (30 orang panelis) terhadap 5 formulasi cookies tersebut. yaitu F0, F1, F2, F3, dan F4. Parameter yang diberikan yaitu rasa, warna, dan tekstur. Setelah mendapatkan hasil yang paling banyak disukai, kemudian diambil 2 formulasi cookies tepung komposit mocaf dan tempe koro gude dengan nilai terbaik untuk dilakukan analisa kimia yang meliputikadar air, kadarabu, kadar protein, kadar lemak, kadarkarbohidrat dan aktivitasantioksidan.

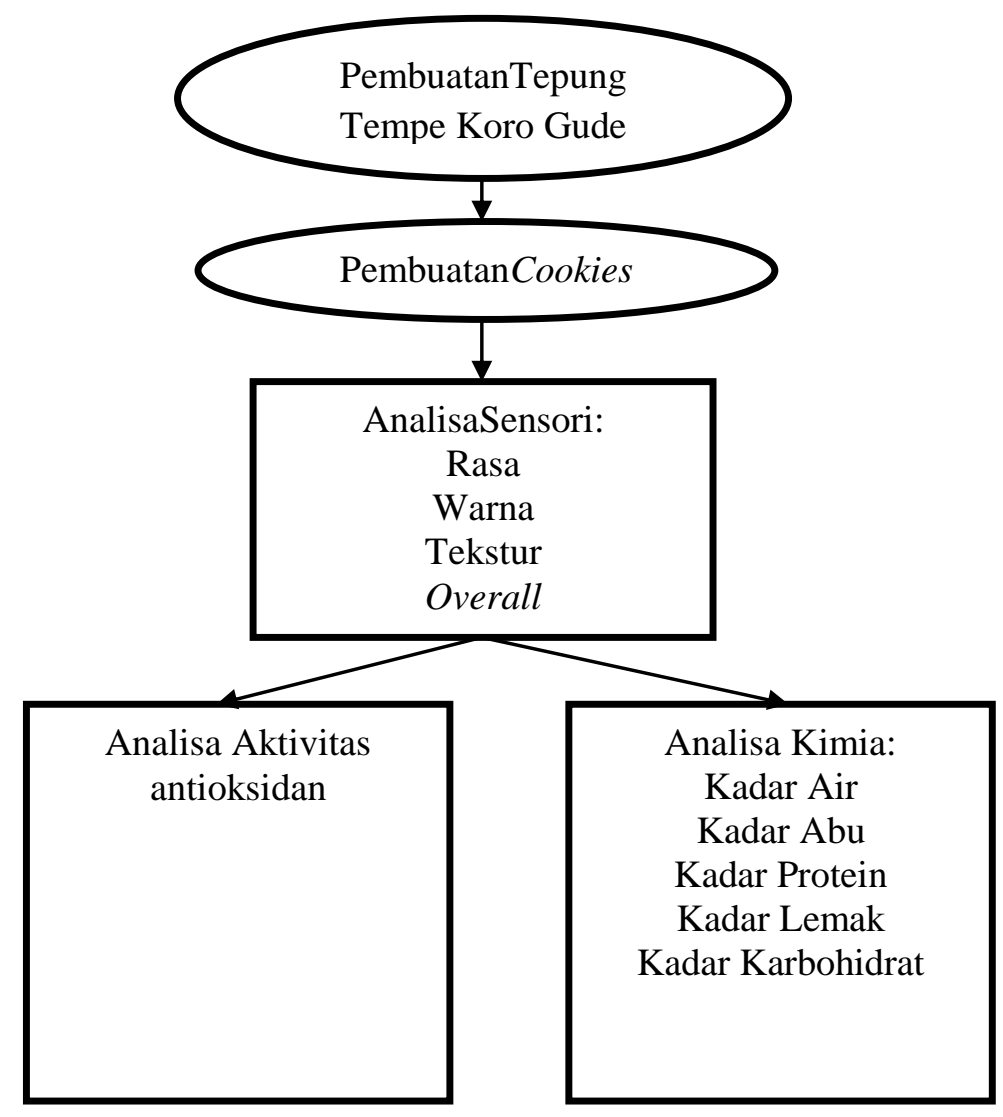

Gambar 1. Desain Penelitian 


\section{PembuatanTepung Tempe Koro Gude}

Pembuatan tepung tempe koro gude dilakukan dengan metode Tranggono et al. (1992) dimodifikasi. Koro gude disortir dahulu, rendam dalam baskom selama 24 jam (setiap 6 jam sekali air diganti). Kemudian, koro direbus dalam panci berisi air bersih selama 25 menit. Setelah mendidih dan agak lunak, angkat koro gude dari panci dengan menggunakan saringan dan kemudian hilangkan kulit koro, dibilas dan selanjutnya dikukus selama 25 menit. Setelah itu koro gude didinginkan dan dibilas kembali dengan air bersih. Koro gude kemudian diberi ragi dan diletakkan dalam plastik bening yang berpori. Koro gude difermentasi selama 2 hari (48 jam) pada suhu ruang, setelah melewati tahap tersebut koro gude dibiarkan di udara terbuka (selama 24 jam) sehingga jadi tempe koro gude. Tempe koro gude yang sudah jadi di kukus selama 15 menit. Setelah pengukusan, dilakukan proses pengecilan ukuran tempe koro gude. Kemudian tempe di keringkan dengan menggunakan dehumidifier pada suhu $70^{\circ} \mathrm{C}$. Tempe yang sudah kering digiling dan hasil tepung tempe koro gude diayak dengan ayakan 80 mesh.

\section{FomulasiCookies}

Pembuatan cookies koro gude sesuai formulasi Ho \& Abdul Latif (2016) dengan penggantian penggunaan tepung mocaf dan tepung tempe koro gude, karena hasil akhir kurang diterima sehingga formulasi dimodifikasi. Berikut merupakan formulasi pembuatan cookies dengan menggunakan 5 konsentrasi perbandingan tepung tempe koro gude dan mocaf. Formulasi cookies tepung komposit mocaf dan tempe koro gude dilihat pada Tabel 1.

Tabel 1. Formulasi Cookies Tepung Komposit Mocaf danTempe Koro Gude

\begin{tabular}{lllllc}
\hline \multirow{2}{*}{ Bahan } & \multicolumn{5}{l}{ Substitusi Tepung Tempe Koro Gude dan Mocaf } \\
\cline { 2 - 6 } & F0 & F1 & F2 & F3 & F4 \\
\hline Tepung Mocaf (gram) & 180 & 171 & 162 & 153 & 144 \\
\hline $\begin{array}{l}\text { Tepung Tempe Koro } \\
\text { Gude (gram) }\end{array}$ & - & 9 & 18 & 27 & 36 \\
\hline Margarin (gram) & 100 & 100 & 100 & 100 & 100 \\
\hline Gula pasir (gram) & 100 & 100 & 100 & 100 & 100 \\
\hline Telur (butir) & 1 & 1 & 1 & 1 & 1 \\
\hline Susu bubuk & 6 & 6 & 6 & 6 & 6 \\
(sendok makan) & & & & & 2 \\
\hline Vanilla essence (ml) & 2 & 2 & 2 & 2 & 3,5 \\
\hline Baking soda (gram) & 3.5 & 3,5 & 3,5 & 3,5 & \\
\hline
\end{tabular}




$\frac{\text { Garam (gram) }}{\text { Keterangan: }}$
F0 $=100 \%$ Mocaf (kontrol)
F1 $=5 \%$ Tepung Tempe Koro Gude $: 95 \%$ Mocaf
F2 $=10 \%$ Tepung Tempe Koro Gude $: 90 \%$ Mocaf
F3 $=15 \%$ Tepung Tempe Koro Gude $: 85 \%$ Mocaf
F4 $=20 \%$ Tepung Tempe Koro Gude $: 80 \%$ Mocaf

\section{PembuatanCookies}

Pembuatan cookies koro gude dilakukan dengan metode Ho \& Abdul Latif (2016) dimodifikasi. Margarin $100 \mathrm{~g}$ dan gula pasir $100 \mathrm{~g}$ dikocok hingga halus, ditambah telur 1 butir dan vanilla essence 2 $\mathrm{ml}$ kocok hingga mengembang (krim). Tepung $180 \mathrm{~g}$ (sesuai formulasi), susu bubuk $6 \mathrm{sdm}$, garam $1 \mathrm{~g}$, baking powder 3,5 g, dimasukkan dalam adonan krim, dikocok hingga merata dan menjadi liat. Adonan digulung dengan menggunakan rolling pin dan di potong bulat dengan diameter $3 \mathrm{~cm}$ ketebalan $3 \mathrm{~mm}$. Adonan dioven pada suhu $160^{\circ} \mathrm{C}$ selama kurang lebih 25 menit.

\section{Analisa Sensori}

Pengujian organoleptik merupakan manusia sebagai alat utama untuk mengukur daya terima terhadap makanan. Metode yang digunakan adalah analisa uji hedonik. Analisis dilakukan oleh 30 panelis tidak terlatih untuk mengetahui daya terima konsumen. Parameter yang diujikan adalah parameter tingkat kesukaan terhadap lima formulasi cookies yaitu rasa, warna, dan tekstur. Pengujian dilakukan panelis terhadap sampel yang telah diberi kode tiga digit secara acak dengan mencicipi sampel secara berurutan dari sebelah kiri ke kanan. Pengukuran daya terima didasarkan pada lima skala hedonik, yaitu 1 = sangat tidak suka, 2 = tidak suka,
$3=$ agak suka, $4=$ suka, dan $5=$ sangat suka. Selanjutnya, 2 formulasi terbaik dari cookies mocaf dan tepung tempe koro gude yang dipilih panelis kemudian akan digunakan untuk penelitian utama (Setyaningsih et al., 2010).

\section{Analisa kimia meliputi :}

\section{Analisa Kadar Air}

Analisa kadar air dilakukan dengan menggunakan metode thermogavimetri (pengeringan). Pertama, cawan porselin kosong yang akan digunakan dikeringkan dalam tanur bersuhu $600^{\circ} \mathrm{C}$ selama 1 jam dan dioven pada suhu $100^{\circ}-105^{\circ} \mathrm{C}$ selama 30 menit. Cawan kemudian dimasukkan kedalam desikator selama 30 menit lalu ditimbang dan dicatat beratnya. Sampel cookies yang telah dihaluskan kemudian ditimbang sebanyak $\pm 2 \mathrm{~g}$ dalam cawan kering, lalu dicatat berat cawan berisi sampel. Sampel setelah itu dikeringkan dalam oven bersuhu $100-105^{\circ} \mathrm{C}$ selama \pm 16-18 jam. Sampeldancawan yang telah dikeringkan kemudian dimasukkan dalam desikator selama 15 menit, lalu beratnya ditimbang. Kadar air berat keringnya (dry basis) kemudian dihitung menggunakan rumus berikut:

Kadar air $($ dry basis $)=$

$\frac{\text { (berat cawantsampel) -(berat cawantsampel kering) }}{\text { (berat cawantsampel kering)-(berat cawan kosong) }} \times 100 \%$

(Sudarmadji et al., 2007).

\section{Analisa Kadar Abu}

Pertama-tama, cawan porselin kosong dikeringkan dalam tanur pada suhu $600^{\circ} \mathrm{C}$ selama 1 jam dan dioven pada suhu $100^{\circ}-105^{\circ} \mathrm{C}$ selama 30 menit. Kemudian cawan dimasukkan kedalam desikator selama 30 menit lalu ditimbang dan dicatat beratnya. Selanjutnya, sampel dihaluskan dan ditimbang sebanyak 2gram 
dimasukkan dalam cawan kering lalu dicatat berat cawan berisi sampel. Sampel diabukan dalam tanur bersuhu $550^{\circ} \mathrm{C}$ selama 3-5 jam. Pengabuan dilakukan hingga dihasilkan abu berwarna abu putih keabu-abuan (pembakaran sempurna) dengan berat konstan. Setelah itu, cawan dibiarkan dingin selama \pm 30 menit lalu dimasukkan dalam oven selama 30 menit pada suhu $105^{\circ} \mathrm{C}$. Setelah di oven, kemudian didinginkan dalam desikator selama 30 menit dan ditimbang. Kadar abu dapat dihitung dengan rumus:

Kadar $\mathrm{abu}=$

$\frac{(\text { berat cawan }+ \text { abu })-\text { berat cawan }}{(\text { berat cawan }+ \text { sampel })-\text { berat cawan }} \times 100 \%$

(Sudarmadji et al., 2007).

\section{Analisa Kadar Protein}

Analisa protein yang digunakan adalah dengan metode Kjeldahl. Pertamatama, tabung destruksi yang akan digunakan dicuci dengan $\mathrm{HCl} 0,1 \mathrm{~N}$ dan bilas dengan aquades. Sampel yang sudah dihaluskan dimasukkan ke dalam tabung sebanyak 0,5 gram, ditambah 7 gram $\mathrm{K}_{2} \mathrm{SO}_{4}, 0,35$ gram $\mathrm{HgO}$, dan $15 \mathrm{~mL} \mathrm{H}_{2} \mathrm{SO}_{4}$ pekat dan destruksi selama 3 jam di ruang asam. Setelah destruksi dan sampel dingin, cuci sampel dengan $50 \mathrm{~mL}$ aquades dan masukkan ke dalam labu destilasi. Tambahkan $\mathrm{NaOH}: \mathrm{Na}_{2} \mathrm{~S}_{2} \mathrm{O}_{3}$ sebanyak 70 mL kedalam labu destilasi dan tambahkan zinc secukupnya agar sampel tidak berbusa. Alat destilasi dipasang dan letakkan Erlenmeyer berisi $25 \mathrm{~mL}$ asam borat $4 \%$ untuk menangkap destilat. Destilasi dilakukan hingga diperoleh destilat mencapai $75 \%$ dari volume awal. Setelah itu, tambahkan 2 tetes metil red blue kedalam Erlenmeyer berisi destilat dan titrasi dengan $\mathrm{HCl} 0,1 \mathrm{~N}$ hingga berubah warna menjadi ungu jernih. Hitung kadar protein dengan rumus sebagai berikut:
$\% \mathrm{~N}=\frac{m l H C l \times N H C l \times 14,008}{\text { berat } \operatorname{sampel}(g) \times 1000} \times 100 \%$

$\%$ Protein $=\% \mathrm{~N} x$ faktor konversi $(6,25)$

(Sudarmadji et al., 2007).

\section{Analisa Lemak}

Analisa lemak dilakukan dengan menggunakan metode soxhlet. Pertamatama, cookies yang sudah dihaluskan sebanyak 1 gram dibungkus menggunakan kertas saring. Kemudian dimasukkan ke dalam labu ekstraksi. Isi labu ekstraksi dan labu lemak dengan pelarut heksan secukupnya dan lakukan ekstraksi selama \pm 3 jam. Setelah itu, sampel dikeluarkan dari labu ekstraksi. Heksan yang bercampur dengan lemak dipanaskan hingga heksan naik kembali ke labu ekstraksi. Pemanasan dihentikan ketika campuran heksan dan lemak dalam labu tersisa sedikit. Campuran heksan dan lemak dipindahkan ke dalam cawan yang sudah diketahui beratnya (A). Cawan berisi campuran heksan dan lemak dioven selama 2 jam pada suhu $100^{\circ} \mathrm{C}$. Masukkan cawan ke dalam desikator selama 30 menit, kemudian timbang cawan hingga diperoleh berat konstan (B). Kadar lemak dihitung dengan rumus:

Lemak total

$=\frac{(B-A)}{\text { berat sampel awal }(g)} \times 100 \%$

(Sudarmadji et al., 2007).

\section{Analisa Karbohidrat}

\begin{tabular}{lcr}
\multicolumn{1}{c}{ Analisis } & kadar & karbohidrat \\
menggunakan & metode & analisa \\
Carbohydrate by Difference, & dimana \\
perhitungannya menggunakan & penentuan \\
secara individual dari & konstituen \\
kandungan yang lain (protein, lemak, air
\end{tabular}


dan abu) yang kemudian dijumlahkan dan dikurangkan dari total berat sampel.

Carbohydrate by Difference $=100 \%-$

$\%($ berat $($ protein + lemak + air + abu $)$

(Sudarmadji et al., 2007).

\section{Analisa Aktivitas Antioksidan}

\begin{abstract}
Pembuatan larutan DPPH $\quad(2,2$ difenil-1-pikrilhidrazil) dengan cara mereaksikan 0,1 methanol dengan 3,9 ml larutan DPPH $6 \times 10^{-5} \mathrm{~mol} / \mathrm{L}$. kemudian antioksidan diukur dengan menggunakan spektrofotometer dengan panjang gelombang $515 \mathrm{~nm}$. Selanjutnya pembuatan larutan sampel dengan cara menimbang sampel yang telah dihaluskan sebanyak 0,5gram dimasukkan dalam tabung reaksi, kemudian diekstrak dengan melarutkannya kedalam etanol $5 \mathrm{ml}$ dan didiamkan selama 2 jam. Kemudian hasil ekstraksi diambil sebanyak $0,1 \mathrm{ml}$ dan direaksikan dengan larutan DPPH sebanyak 3,9 ml didiamkan selama 30 menit. Aktivitas antioksidan diukur pada panjang gelombang $515 \mathrm{~nm}$ dengan menggunakan spektrofotometer. Aktivitas antioksidan dapat dilihat dari perubahan warna ungu menjadi kekuningan.
\end{abstract}

Aktivitas antioksidan dapat dihitung dengan persamaan:

$\%$ aktivitas antioksidan $=$

$\left(1-\frac{\text { Absorbansi Sampel }}{\text { Absorbansi Kontrol }}\right) \times 100 \%$

(Sudarmadji et al., 2007).

\section{Analisa Data}

Hasil pengujian dalam penelitian akan dianalisis menggunakan perangkat lunak Microsoft Excel dan SPSS (Statistical Package for The Social Science for Windows) versi 21.0. Hasil uji organoleptik diuji statistik non parametrik Kruskal Wallis dan Mann Whitney untuk mengetahui adanya perbedaan antar perlakuan. Untuk hasil uji fisik dan uji kimia diuji statistik parametrik uji $\mathrm{T}$ pada tingkat kepercayaan 95\% $(\mathrm{P} \leq 0,05)$.

\section{HASIL PENELITIAN}

\section{AnalisaSensori}

Hasil penelitian uji organoleptik dengan menggunakan uji Kruskal wallis dapat dilihat pada Tabel 2. Dua formulasi tertinggi cookies mocaf dan tepung tempe koro gude pada parameter rasa, warna, tekstur dan overall adalah sampel F2 dan F3. Pada parameter rasa F2 (cookies mocaf $90 \%$ dan tepung tempe koro gude 10\%) memiliki nilai 3,27 $\pm 1,41^{\mathrm{a}}$ dan $\mathrm{F} 3$ (cookies mocaf $85 \%$ dan tepung tempe koro gude $15 \%$ ) memiliki nilai $3,27 \pm 1,41^{\text {a }}$ menujukkan tidak ada beda nyata pada tingkat kepercayaan 95\% ( $\mathrm{P}>0,05)$. Pada parameter warna F2 (cookies mocaf 90\% dan tepung tempe koro gude 10\%) memiliki nilai lebih tinggi yaitu $3,80 \pm$ $0,96^{\mathrm{ab}}$ dari F3 (cookies mocaf $85 \%$ dan tepung tempe koro gude 15\%) yang memiliki nilai $2,73 \pm 1,43^{\text {ac }}$ menujukkan tidak ada beda nyata pada tingkat kepercayaan $\quad 95 \% \quad(\mathrm{P}>0,05) . \quad$ Pada parameter tekstur F2 (cookies mocaf 90\% dan tepung tempe koro gude 10\%) memiliki nilai lebih rendah yaitu $2,83 \pm$ $1,20^{\mathrm{bc}}$ dari F3 (cookies mocaf $85 \%$ dan tepung tempe koro gude 15\%) yang memiliki nilai $3,10 \pm 1,37^{\text {ac }}$ menujukkan ada beda nyata pada tingkat kepercayaan 95\% ( $\mathrm{P}>0,05)$.

Tabel 2. Hasil uji sensori ranking hedonik cookies mocaf dan tepung tempe koro gude 
Jurnal PRAXIS | Vol. 3 | No. 1 | September 2020

\begin{tabular}{lllll}
\hline Sampel & Rasa & Warna & Tekstur & Overall \\
\hline F0 & $3,10 \pm 1,54^{\mathrm{a}}$ & $3,27 \pm 1,89^{\mathrm{a}}$ & $3,70 \pm 1,26^{\mathrm{a}}$ & $3,17 \pm 1,70^{\mathrm{a}}$ \\
F1 & $2,63 \pm 1,16^{\mathrm{a}}$ & $2,70 \pm 1,12^{\mathrm{a}}$ & $2,60 \pm 1,28^{\mathrm{bc}}$ & $2,80 \pm 1,24^{\mathrm{a}}$ \\
F2 & $3,27 \pm 1,41^{\mathrm{a}}$ & $3,80 \pm 0,96^{\mathrm{ab}}$ & $2,83 \pm 1,20^{\mathrm{bc}}$ & $3,37 \pm 1,38^{\mathrm{a}}$ \\
F3 & $3,27 \pm 1,41^{\mathrm{a}}$ & $2,73 \pm 1,17^{\mathrm{ac}}$ & $3,10 \pm 1,37^{\mathrm{ac}}$ & $2,89 \pm 1,43^{\mathrm{a}}$ \\
F4 & $2,73 \pm 1,57^{\mathrm{a}}$ & $2,50 \pm 1,43^{\mathrm{ac}}$ & $2,77 \pm 1,72^{\mathrm{bc}}$ & $2,80 \pm 1,42^{\mathrm{a}}$ \\
\hline
\end{tabular}

Keterangan :

$\mathrm{F} 0=$ Cookies mocaf $100 \%$

$\mathrm{F} 1=$ Cookies mocaf $95 \%$ dan tepung tempe koro gude $5 \%$

$\mathrm{F} 2=$ Cookies mocaf $90 \%$ dan tepung tempe koro gude $10 \%$

$\mathrm{F} 3=$ Cookies mocaf $85 \%$ dan tepung tempe koro gude $15 \%$

F4 = Cookies mocaf $80 \%$ dan tepung tempe koro gude $20 \%$
- Semua nilai merupakan nilai mean \pm standar deviasi dan dianalisa berdasarkan 30 panelis

- Ranking penilaian Analisa sensori dari angka 1 = sangat tidak suka sampai 5 = sangat suka

- Nilai dengan superscript yang berbeda menunjukkan adaperbedaan nyata antar perlakuan pada tingkat kepercayaan 95\% $(\mathrm{P} \leq 0,05)$ berdasarkan ANOVA dengan pengujian Kruskal Wallis dan dilanjutkan dengan Mann Withney test sebagai uji beda.

Gambar 2. Cookies F0 dengan penambahan tepung mocaf 100\%, F1 dengan penambahan mocaf $95 \%$ dan tepung tempe koro gude 5\%, F2 dengan penambahan mocaf $90 \%$ dan tepung tempe koro gude $10 \%, \mathrm{~F} 3$ dengan penambahan mocaf $85 \%$ dan tepung tempe koro gude $15 \%, \mathrm{~F} 4$ dengan penambahan mocaf $80 \%$ dan tepung tempe koro gude $20 \%$.

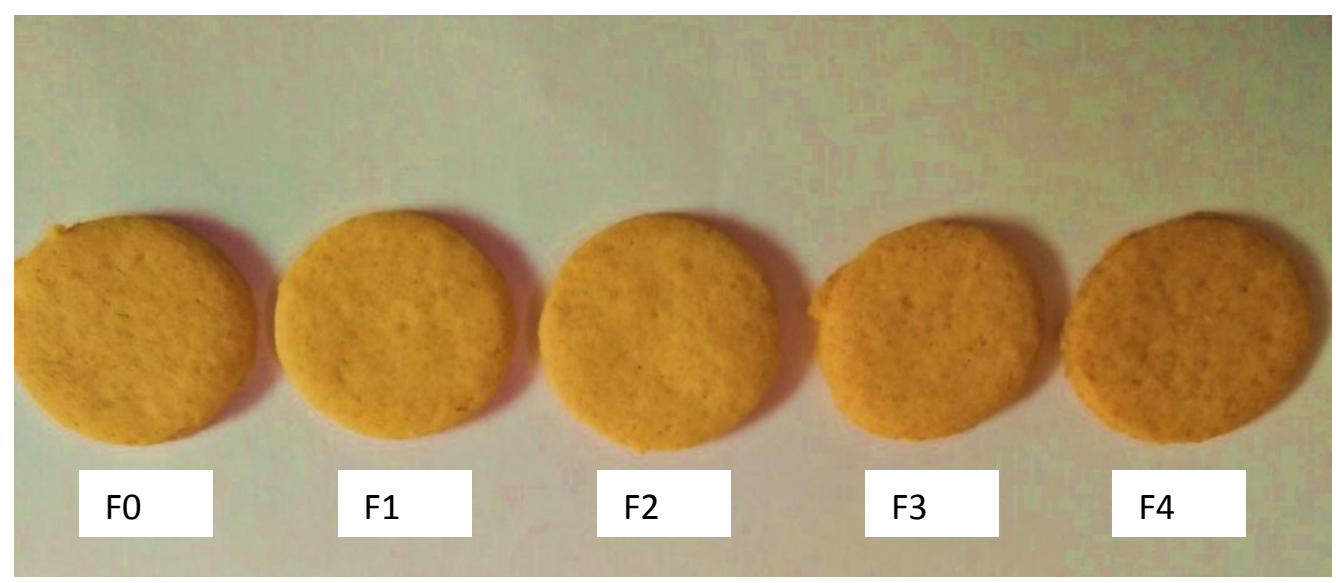




\section{Analisa Kimia}

Hasil analisa kimia dilakukan pada F2 dan F3 karena formulasi tersebut yang paling banyak disukai oleh panelis. Kadar air F3 (4,99\%) memiliki nilai lebih tinggi dari F2 (4,75\%). Kadar abu F3 (1,88\%) memiliki nilai lebih tinggi dari F2 (1,86\%). Kadar protein F3 (7,59\%) memiliki nilai lebih tinggi dari F2 (6,49\%). Kadar lemak F3 (15,08\%) memiliki nilai lebih tinggi dari F2 (14,52\%), seperti terlihat pada Tabel 3.

Tabel 3. Hasil uji analisis kimia cookies mocaf dan tepung tempe koro gude

\begin{tabular}{lll}
\hline \multirow{2}{*}{ Parameter } & Sampel & \\
\cline { 2 - 3 } & F2 & F3 \\
\hline Kadar air & $4,75 \pm 0,10^{\mathrm{a}}$ & $4,99 \pm 0,08^{\mathrm{b}}$ \\
Kadar abu & $1,86 \pm 0,12^{\mathrm{a}}$ & $1,88 \pm 0,08^{\mathrm{a}}$ \\
Kadar protein & $6,49 \pm 0,18^{\mathrm{a}}$ & $7,59 \pm 0,33^{\mathrm{b}}$ \\
Kadar lemak & $14,52 \pm 2,09^{\mathrm{a}}$ & $15,08 \pm 0,67^{\mathrm{a}}$ \\
Kadar karbohidrat & $72,38 \pm 2,09^{\mathrm{a}}$ & $70,45 \pm 0,84^{\mathrm{a}}$ \\
Aktivitas antioksidan & $12,86 \pm 1,14^{\mathrm{a}}$ & $21,13 \pm 1,28^{\mathrm{b}}$ \\
\hline
\end{tabular}

Keterangan :

$\mathrm{F} 2$ = Cookies mocaf $90 \%$ dan tepung tempe koro gude $10 \%$

F3 = Cookies mocaf $85 \%$ dan tepung tempe koro gude $15 \%$

- Semua nilai merupakan nilai mean \pm standar deviasi

- Nilai dengan superscript yang berbeda menunjukkan ada perbedaan nyata antar perlakuan pada tingkat kepercayaan $95 \%$ $(\mathrm{P} \leq 0,05)$ berdasarkan uji beda

\section{DISKUSI}

Hasil analisis sensori menunjukkan bahwa cookies tepung komposit mocaf dan tempe koro gude yang memiliki skor tinggi adalah F2 (tepung komposit mocaf 90\% dan tepung tempe koro gude 10\%) dan F3 (tepung komposit mocaf $85 \%$ dan tepung tempe koro gude 15\%). Hal tersebut karena tepung tempe koro gude masih memiliki flavor beany yang disebabkan oleh enzim lipoksigenase, sehingga cookies dengan formulasi F4 kurang disukai. 
Hasil pengujian kadar air pada Tabel 3 dapat dilihat bahwa nilai rata-rata kadar air F2 lebih rendah yaitu sebesar $4,75 \%$ dari F3 yaitu sebesar 4,99\%. Kedua sampel tersebut memiliki nilai kadar air dibawah 5\%. Hal ini menunjukkan bahwa kadar air yang terkandung dalam kedua sampel memenuhi syarat mutu cookies. Syarat mutu cookies berdasarkan SNI, kadar air maksimumnya adalah 5\% (Ade, et al., 2012). Kadar air ini dipengaruhi oleh penambahan tepung tempe koro gude yang mengakibatkan kandungan protein meningkat, sehingga akan meningkatkan water holding capacity (WHC) (Zayas, 1997 dalam Hapsari, 2009).

Hasil pengujian kadar abu pada Tabel 3 dapat dilihat bahwa nilai rata-rata kadar abu F2 sebesar 1,86\% dan F3 sebesar $1,88 \%$. Kedua sampel tersebut memiliki nilai kadar abu dibawah $2 \%$. Hal ini menunjukkan bahwa kadar abu yang terkandung dalam kedua sampel memenuhi syarat mutu cookies yaitu maksimal 2\% (SNI, 1992). Nilai kadar abu yang tinggi ini dipengaruhi karena adanya penambahan tepung tempe koro gude, di dalam koro gude mengandung mineral zat besi sebesar $1,80 \mathrm{mg}$ pada polong muda dan $4,00 \mathrm{mg}$ pada biji, serta kandungan fosfor yang cukup tinggi yaitu $174 \mathrm{~g}$ per $100 \mathrm{~g}$ koro gude pada polong muda dan pada biji sekitar $275 \mathrm{~g}$ per $100 \mathrm{~g}$ koro gude (Rukmana, 1999). Selain dari tepung tempe koro gude kandungan abu berasal dari margarin yang digunakan dalam pembuatan cookies karena di dalam margarin mengandung mineral fosfor dan zat besi (Rosalin, 2006). Penambahan telur juga mempengaruhi kadar abu produk yaitu dalam kuning telur mengandung lesitin (Oktavia, 2008).

Hasil pengujian kadar protein pada Tabel 3 dapat dilihat bahwa nilai rata-rata kadar protein F2 sebesar 6,49\% dan F3 sebesar 7,59\%. Kedua sampel tersebut memiliki nilai kadar protein lebih dari $6 \%$. Hal ini menunjukkan bahwa kadar protein yang terkandung dalam kedua sampel memenuhi syarat mutu cookies yaitu nilai minimum kadar protein dalam cookies adalah $6 \%$. Kadar protein yang terkandung dalam tepung mocaf sebesar $1,93 \%$ dan pada biji koro gude kandungan proteinnya sebesar 20,70 g per 100 g. Sehingga semakin banyak tepung tempe koro gude yang ditambahkan maka kandungan protein dalam bahan pangan akan semakin meningkat (Mulyani, 2015).

Hasil pengujian kadar lemak pada Tabel 3 dapat dilihat bahwa nilai rata-rata kadar lemak F2 sebesar 14,52\% dan F3 sebesar $15,08 \%$. Hal ini sudah sesuai dengan syarat mutu cookies dengan nilai minimum kandungan lemak sebesar 9,5\% (DSN, 1992). Pada umumnya, lemak yang terkandung dalam cookies berasal dari telur dan margarin (Oktavia, 2008). Margarin mengandung lemak yang cukup besar. Lemak yang terkandung dalam margarin terikat dalam bentuk lipoprotein, yang jika ditambahkan dalam adonan maka adonan akan memiliki kandungan lemak yang tinggi (Lingga, 2012). Hasil pengujian kadar lemak menunjukkan tidak ada beda nyata antara F2 dan F3 pada tingkat kepercayaan 95\% (P>0,05). Hal ini karena penggunaan tepung mocaf dan tepung tempe koro gude hanya mempengaruhi sedikit kandungan lemak dalam cookies. Kandungan lemak tepung mocaf hanya sebesar 2,72\% (Mulyani, 2015). Sedangkan pada biji koro gude, kandungan lemaknya sebesar 1,40 g per $100 \mathrm{~g}$ koro gude (Rukmana, 1999).

Berdasarkan hasil pengujian kadar karbohidrat pada Tabel 3 dapat dilihat bahwa nilai rata-rata kadar karbohidrat $\mathrm{F} 2$ sebesar 72,38\% dan F3 sebesar 70,45\%. Kedua sampel tersebut memiliki nilai kadar karbohidrat lebih dari 70\%. Hal ini menunjukkan bahwa kadar karbohidrat yang terkandung dalam kedua sampel memenuhi syarat mutu cookies. Nilai 
kandungan karbohidrat dalam cookies minimum 70\% (DSN, 1992; Ade, et al 2012). Nilai kadar air F2 lebih tinggi dari $\mathrm{F} 3$, hasil pengujian kadar air menunjukkan tidak ada beda nyata antara F2 dan F3 pada tingkat kepercayaan 95\% (P>0,05). Hal ini disebabkan karena penggunaan tepung mocaf pada sampel F2 yang lebih banyak dibandingkan dengan F3. Tepung mocaf memiliki kandungan pati yang tinggi, yaitu sekitar 87,3\% (Salim, 2011). Semakin banyak penambahan tepung mocaf dalam pembuatan cookies maka akan semakin tinggi kadar karbohidrat dalam cookies (Lina, 2012).

Nilai rata-rata aktivitas antioksidan F2 sebesar 12,86\% lebih rendah dari nilai F3 sebesar 21,13\%. Tingginya nilai aktivitas antioksidan ini menunjukkan adanya senyawa antioksidan yang terkandung dalam koro gude. Senyawa antioksidan yang terkandung dalam koro gude adalah antosianin. Antosianin merupakan pigmen yang memberikan warna merah keunguan pada bahan pangan (Kurnia, 2008). Pengukuran aktivitas antioksidan dilakukan dengan menggunakan DPPH, pada saat DPPH bereaksi dengan senyawa yang mendonorkan hydrogen akan membentuk senyawa 1,1-difenil-2-pikrilhidrazin (DPPH-H) maka DPPH akan tereduksi dan mengakibatkan perubahan warna pada larutan sampel yang mengandung antioksidan (Zuhra, dkk, 2008). Larutan DPPH yang semula warna ungu tua ketika dicampur dengan larutan sampel yang diduga mengandung antioksidan maka warna ungu tua pada larutan DPPH akan berkurang (Molyneux, 2004). Semakin banyak kandungan antioksidan dalam cookies maka warna ungu dalam DPPH akan semakin berkurang dan nilai absorbansi akan semakin kecil (Zuhra, dkk, 2008). Selain itu, adanya kandungan polifenol yang terdapat pada koro gude akan mengikat matriks protein, sehingga kapasitas antioksidan akan mengalami peningkatan. Polifenol yang berikatan dengan protein mampu mentasabilkan protein sehingga antioksidan akan meningkat selama pemanasan (Loganayaki, 2011). Hal ini menunjukkan bahwa semakin banyak tepung tempe koro gude yang digunakan maka nilai absorbansi akan semakin rendah dan nilai aktivitas antioksidan akan semakin tinggi.

\section{KESIMPULAN}

Cookies tepung komposit mocaf dan tempe koro gude yang disulai panelis adalah F2 (tepung komposit mocaf 90\% dan tepung tempe koro gude 10\%) dan F3 (tepung komposit mocaf $85 \%$ dan tepung tempe koro gude 15\%). Penggunaan tepung tempe koro gude dalam tepung komposit tersebut meningkatkan kandungan gizi dari cookies sehingga memenuhi standar SNI cookies.

\section{DAFTAR PUSTAKA}

AACC. 2000. Approved methods of the American association of cereal chemists (10th ed.). St. Paul: American Association of Cereal Chemists

Ade, I.C., Ingbian, and Abu. 2012. Physycal Chemical and Sensory Properties of Baked Products from Blends of Wheat and African Yam Bean (Sphenoostylis stehocorpa) Water-Extractable Protein. Nigerian Food Journal. NIFOJ Vol. 30 No. 1, pages 109-115

Asmawan, et al. 2014. Analisis Kebijakan Impor Tepung Gandum, IPB: Bogor

Dewan Standardisasi Nasional (DSN). 1992. Mutu dan Cara Uji Biskuit (SNI 01-197-1992). Jakarta. Dewan Standardisasi Nasional.

Gomez, K. A. dan A. A. Gomez. 1995. Prosedur Statistik untuk Penelitian 
Pertanian. (Terjemahan). E. Syamsudin dan J. S. Baharsjah. UI Press. Jakarta. Halaman 698.

Ho LH, and Abdul Latif NWB. 2016. Nutritional composition, physical properties, and sensory evaluation of cookies prepared from wheat flour and pitaya (Hylocereus undatus) peel flour blends. Cogent Food Agric. 2(1):1136369.

Lina, I. 2012. Pembuatan Mocaf (Modified Cassava Flour) dengan Proses Fermentasi Menggunakan Lactobacillus plantarum, saccharomyces cerevisiae dan Rhizopus oryzae. Jurnal Pangan, 1 (1): $1-6$

Loganayaki, N., Siddhuraju, P. \& Manian, S.,2011. A Comparative Study on In Vitro Antioxidant Activity of The Legumes Acacia Auriculiformis and Acacia Ferruginea With A Conventional Legume Cajanus Cajan. CyTA Journal of Food, 9 No. 1, pp.37-41.

Molyneux, P. 2004. The Use of The Stable Free Radical Diphenylpicrylhydrazyl (DPPH) for Estimating Antioxidant Activity. Songklanakarin J. Sci. Technology. 26(2), 211-21

Oktavia, Dwi R. 2008. Evaluasi Produk Good Time Cookies di PT. Amott's Indonesia Sebagai Dasar Penentuan Nilai Tambah Produk. Skripsi. IPB. Bogor.

Rosmisari, A. 2006. Review: Tepung Jagung Komposit, Pembuatan dan Pengolahannya. Seminar Nasional Teknologi Inovatif Pascapanen Pengembangan Pertanian, Bogor.

Rukmana, R. 1999. Kacang Gude Budidaya dan Penanganan Pasca Panen. Yogyakarta: Kanisius.
Salim, E. 2011. Mengolah Singkong menjadi Tepung Mocaf Bisnis Produk Alternatif Pengganti Terigu. Andi Offset. Yogyakarta.

Setyaningsih, D., Apryanto, A. dan Sari, M. P. 2010. Analisis Sensori untuk Industri Pangan dan Agro. IPB Press. Bogor.

Sudarmadji. S., B. Haryono dan Suhardi. 2007. Prosedur Analisis Bahan Makanan dan Pertanian. Liberty. Yogyakarta.

Tranggono, Sutardi, dan Kuswijayanto, B. 1992. Aktivitas Tripsin Inhibitor Selama Proses Pembuatan Tempe Koro Benguk (Mucuna prurient), Kacang Tolo (Vignaungulgulata) dan Gude (Cajanus cajan). Fakultas Teknologi Pertanian. UGM. Yogyakarta.

Winarno F.G. 2004. Kimia Pangan dan Gizi. PT Gramedia Pustaka Utama. Jakarta.

Zayas, J.F. 1997. Functionality of Proteins in Food. Springer-Verlag, Berlin. 358 pp. dalam Hapsari, A.W. 2009. Studi Sifat Fisikokimia, Fungsional Protein, dan Kapasitas Antioksidan pada Konsentrat Protein Kecambah Kacang Komak (Lablab purpureus (L.) sweet). Skripsi. IPB

Zuhra, C.F., et al,. 2008. Aktivitas Antioksidan Senyawa Flavonoid Dari Daun Katuk (Sauropus androgunus (L) Merr.). Departemen Kimia FMIPA USU Jurnal Biologi Sumatera Vol 3 No. 1. Halaman: 710 